\title{
Status of tobacco viruses in Serbia and molecular characterization of tomato spotted wilt virus isolates
}

\author{
I. STANKOVIĆ ${ }^{1}$ A. BULAJIĆ ${ }^{1}$, A. VUČUROVIĆ ${ }^{1}$, D. RISTIĆ ${ }^{1}$, K. MILOJEVIĆ $^{1}$, J. BERENJI², B. KRSTIĆ ${ }^{*}$ \\ ${ }^{1}$ Institute of Phytomedicine, Department of Phytopathology, University of Belgrade-Faculty of Agriculture, Nemanjina 6, 11080 \\ Belgrade, Serbia; ${ }^{2}$ Institute of Field and Vegetable Crops, Maksima Gorkog 30, 21000 Novi Sad, Serbia
}

Received April 15, 2011; accepted November 16, 2011

\begin{abstract}
Summary. - In a four-year survey to determine the presence and distribution of viruses in tobacco crops at 17 localities of the Vojvodina Province and Central Serbia, 380 samples were collected and analyzed by DAS-ELISA. Out of the seven viruses tested, tomato spotted wilt virus (TSWV), potato virus Y (PVY), tobacco mosaic virus (TMV), cucumber mosaic virus (CMV), and alfalfa mosaic virus (AMV) were detected in 37.9, $33.4,28.7,23.9$, and $15.5 \%$ of the total tested samples, respectively. TSWV was the most frequently found virus at the localities of Central Serbia, while PVY and CMV were the most frequent viruses in the Vojvodina Province. Single infections were prevalent in years 2005-2007 and the most frequent were those of PVY. A triple combination of those viruses was most frequent mixed infection type in 2008. The presence of all five detected viruses was confirmed in selected ELISA-positive samples by RT-PCR and sequencing. The comparisons of obtained virus isolate sequences with those available in NCBI, confirmed the authenticity of serologically detected viruses. Phylogenetic analysis based on partial nucleocapsid gene sequences revealed a joint clustering of Serbian, Bulgarian and Montenegrin TSWV isolates into one geographic subpopulation, which was distinct from the other subpopulation of TSWV isolates from the rest of the European countries. The high incidence of viruses in Serbian tobacco crops highlights the importance of enhancing farmers knowledge towards better implementation of control strategies for preventing serious losses.
\end{abstract}

Keywords: tobacco; survey; viruses; DAS-ELISA; RT-PCR; phylogenetic analysis

\section{Introduction}

Tobacco (Nicotiana tabacum L.) is a high-value cash crop that is traditionally grown in Serbia. It is cultivated in approximately 6,000 ha with an annual production of $10,000 \mathrm{t}$ of dried leaves. On a global scale, the production level of tobacco in Serbia is not significant, but it provides a livelihood for a large number of people. The main tobacco

${ }^{*}$ Corresponding author. E-mail: branka.krstic@agrif.bg.ac.rs; fax:+381112193 659 .

Abbreviations: aa $=$ amino acid; $\mathrm{AMV}=$ alfalfa mosaic virus; $\mathrm{CMV}=$ cucumber mosaic virus; MAb = monoclonal antibody; $\mathrm{PVX}=$ potato virus $\mathrm{X} ; \mathrm{PVY}=$ potato virus $\mathrm{Y} ; \mathrm{TCSV}=$ tomato chlorotic spot virus; TMV = tobacco mosaic virus; TRSV = tobacco ringspot virus; $\mathrm{TSWV}=$ tomato spotted wilt virus producing regions in Serbia are located in the Vojvodina Province in northern Serbia, as well as in Central Serbia, with two predominant types of tobacco, Virginia and Burley.

Tobacco viruses are one of the most important limiting factors in tobacco industry (Gooding, 1991; WilliamsWoodward, 2000). In some cases, tobacco viruses could cause a complete crop failure (Chatzivassiliou et al., 2004). More than 20 viruses occur in tobacco naturally, and tobacco can be experimentally infected with more than hundred of viral species (Gooding, 1991). The thrips-transmitted TSWV, the mechanically transmitted TMV, and three aphid-transmitted viruses, PVY, CMV and AMV are thought to be the most prevalent (Mayunga and Kaporia, 2003; Chatzivassiliou et al., 2004). Aphid-transmitted PVX and nematode-transmitted TRSV have been reported to be of minor importance on a worldwide basis (Gooding, 1991). 
Despite the importance of tobacco in Serbia, there is only limited information on the occurrence and distribution of tobacco viruses. Several investigations carried out in the Vojvodina Province of Serbia showed the presence of TSWV, AMV, CMV, PVY, PVX, and TMV (Jasnić et al., 2000; Dukić et al., 2006; Djekić et al., 2008). Outbreaks of viral diseases have occurred during the recent years in many tobacco fields in the Vojvodina Province and Central Serbia, having been associated with severe symptoms which have caused great losses in yield.

A four-year survey on tobacco viruses was conducted in order to give an insight into the composition of virus epidemics in tobacco crops in Serbia, by evaluation of the relative incidence and distribution of viruses through serological testing. This study was also focused on obtaining the molecular evidence of the detected viruses and represents the first attempt of genetic characterization of tobacco virus isolates originating from Serbia. The aim of phylogenetic analysis of TSWV was to determine the genetic relationships of Serbian TSWV tobacco isolates with those from other parts of the world.

\section{Materials and Methods}

Survey and sample collection. During the period from 2005 to 2008 , an extensive survey was conducted in order to determine viruses associated with tobacco crops in three districts of the Vojvodina Province (South Bačka, Srem and Central Banat) and three of the Central Serbia (Mačva, Jablanica and City of Belgrade). After visual inspection of 25 tobacco fields at 17 different localities in order to record virus-like symptoms, a total of 380 samples were randomly collected. Samples of tobacco plants comprised of leaves which exhibited some of the various symptoms, such as stunting, leaf distortion, vein clearing or necrosis, various types of mosaic, yellowing and necrotic patterns. Exception was made in 2007, when samples of symptomless plants were also collected from six fields. Samples were transported and stored at $4^{\circ} \mathrm{C}$ until testing by ELISA.

Serological assay. Samples were tested for the presence of seven tobacco viruses utilizing a double-antibody sandwich (DAS)ELISA kits according to manufacturer's instructions. Commercial antisera for detection of PVY, TSWV, CMV, TMV, PVX, AMV (Loewe Biochemica, Sauerlach, Germany), and TRSV (Neogen Europe Ltd, Scotland, UK) were used. Samples that were PVYpositive using polyclonal antiserum were further analyzed using commercial monoclonal antibody (MAb) for detection of tobacco veinal necrosis $\left(\mathrm{PVY}^{\mathrm{N}}\right)$, stipple-streak $\left(\mathrm{PVY}^{\mathrm{C}}\right)$ and combination of ordinary and stipple-streak $\left(\mathrm{PVY}^{\mathrm{O}+\mathrm{C}}\right)$ strains (Loewe Biochemica, Sauerlach, Germany). Leaf tissue extracts were done in extraction buffer at a ratio of 1:10 (wt/vol). After incubation with $p$-nitrophenyl phosphate (Sigma-Aldrich, St. Louis, MO) at room temperature $\left(23^{\circ} \mathrm{C}\right)$ for $2 \mathrm{hrs}$ in dark, absorbance at $405 \mathrm{~nm}$ was measured with an ELISA microplate reader (DASsrl, Italy). Samples were considered positive if the absorbance value was equal to two times the absorbance of the negative control or higher. Commercial positive and negative controls (Loewe) for each virus, extract from healthy tobacco leaf tissue as well as extraction buffer were included in each ELISA.

RT-PCR detection. To confirm PVY, TSWV, CMV, TMV, and AMV identification, total RNA extracts were obtained from leaves of ELISA-positive plants, using the RNeasy Plant Mini Kit (Qiagen, Hilden, Germany) following the manufacturer's instructions. Tissue sample from healthy tobacco leaf was used as a negative control in RNA extraction and RT-PCR amplification. The amplification of fragment of specific nucleotide sequence of PVY (5'-UTR and P1 gene), TSWV (partial NC gene), CMV (complete of CP gene

Table 1. RT-PCRs used for detection of tobacco viruses

\begin{tabular}{|c|c|c|c|c|c|}
\hline Virus & Primer & Sequence $\left(5^{\prime} \rightarrow 3^{\prime}\right)^{\mathrm{a}}$ & Cycling conditions & $\begin{array}{l}\text { Amplicon } \\
\text { size (bp) }\end{array}$ & Reference \\
\hline \multirow{4}{*}{ TSWV } & CP1 TSWV & TTA ACT TAC AGC TGC TTT & $50^{\circ} \mathrm{C} / 30 \mathrm{~min}, 94^{\circ} \mathrm{C} / 15 \mathrm{~min}, 30 \times\left(94^{\circ} \mathrm{C} / 60\right.$ & \multirow{2}{*}{823} & \multirow{2}{*}{ Chatzivassiliou et al., 2000} \\
\hline & CP2 TSWV & CAA AGC ATA TAA GAA CTT & $\left.\mathrm{s}, 48^{\circ} \mathrm{C} / 60 \mathrm{~s}, 72^{\circ} \mathrm{C} / 60 \mathrm{~s}\right), 72^{\circ} \mathrm{C} / 10 \mathrm{~min}$ & & \\
\hline & TSWVgene F & ATG TCT AAG GTT AAG CTC & $50^{\circ} \mathrm{C} / 30 \mathrm{~min}, 94^{\circ} \mathrm{C} / 15 \mathrm{~min}, 40 \times\left(90^{\circ} \mathrm{C} / 30\right.$ & \multirow{2}{*}{800} & \multirow{2}{*}{ Jain et al., 1998} \\
\hline & TSWVgene R & TTA AGC AAG TTC TGT GAG & $\left.\mathrm{s}, 42^{\circ} \mathrm{C} / 120 \mathrm{~s}, 72^{\circ} \mathrm{C} / 60 \mathrm{~s}\right), 72^{\circ} \mathrm{C} / 60 \mathrm{~min}$ & & \\
\hline \multirow{2}{*}{ PVY } & PVYc & AAT TAA AAC AAC TCA ATA CA & $50^{\circ} \mathrm{C} / 30 \mathrm{~min}, 94^{\circ} \mathrm{C} / 15 \mathrm{~min}, 30 \times\left(94^{\circ} \mathrm{C} / 60\right.$ & \multirow{2}{*}{975} & \multirow{2}{*}{ Glais et al., 2002} \\
\hline & PVYd & TGY GAH CCA CGC ACT ATG AA & $\left.\mathrm{s}, 57^{\circ} \mathrm{C} / 60 \mathrm{~s}, 72^{\circ} \mathrm{C} / 60 \mathrm{~s}\right), 72^{\circ} \mathrm{C} / 10 \mathrm{~min}$ & & \\
\hline \multirow[b]{2}{*}{$\mathrm{CMV}$} & CMV Aulu & CAT GGA TGC TTC TCC RCG AG & \multirow{2}{*}{$\begin{array}{l}50^{\circ} \mathrm{C} / 30 \mathrm{~min}, 94^{\circ} \mathrm{C} / 15 \mathrm{~min}, 35 \mathrm{x}\left(94^{\circ} \mathrm{C} / 30\right. \\
\left.\mathrm{s}, 58^{\circ} \mathrm{C} / 30 \mathrm{~s}, 72^{\circ} \mathrm{C} / 30 \mathrm{~s}\right), 72^{\circ} \mathrm{C} / 10 \mathrm{~min}\end{array}$} & \multirow[b]{2}{*}{850} & \multirow[b]{2}{*}{ Djekić et al., 2008} \\
\hline & CMV Au2d & $\begin{array}{l}\text { CGT AAG CTG GAT GGA CAA } \\
\text { CC }\end{array}$ & & & \\
\hline \multirow[t]{2}{*}{ TMV } & & $\begin{array}{l}\text { ATT TAA GTG GAS GGA AAA } \\
\text { VCA CT }\end{array}$ & \multirow[t]{2}{*}{$\begin{array}{l}50^{\circ} \mathrm{C} / 30 \mathrm{~min}, 94^{\circ} \mathrm{C} / 15 \mathrm{~min}, 35 \mathrm{x}\left(94^{\circ} \mathrm{C} / 60\right. \\
\left.\mathrm{s}, 55^{\circ} \mathrm{C} / 45 \mathrm{~s}, 72^{\circ} \mathrm{C} / 60 \mathrm{~s}\right), 72^{\circ} \mathrm{C} / 10 \mathrm{~min}\end{array}$} & \multirow[t]{2}{*}{805} & \multirow[t]{2}{*}{ Letschert et al., 2002} \\
\hline & TMVspec & CGG TCA GTG CCG AAC AAG AA & & & \\
\hline \multirow{2}{*}{ AMV } & CP AMV1 & TCC ATC ATG AGT TCT TCA C & \multirow{2}{*}{$\begin{array}{l}50^{\circ} \mathrm{C} / 30 \mathrm{~min}, 94^{\circ} \mathrm{C} / 15 \mathrm{~min}, 35 \mathrm{x}\left(95^{\circ} \mathrm{C} / 60\right. \\
\left.\mathrm{s}, 49^{\circ} \mathrm{C} / 60 \mathrm{~s}, 72^{\circ} \mathrm{C} / 120 \mathrm{~s}\right), 72^{\circ} \mathrm{C} / 10 \mathrm{~min}\end{array}$} & \multirow{2}{*}{751} & \multirow{2}{*}{ Finetti-Sialer et al., 1997} \\
\hline & CP AMV2 & AGG ACT TCA TAC CTT GAC C & & & \\
\hline
\end{tabular}


Table 2. NC-gene sequences of TSWV isolates used for phylogenetic analysis

\begin{tabular}{|c|c|c|c|}
\hline Isolate name & Geographical origin & Host plant & Acc. No. \\
\hline Is-56 & Montenegro & Nicotiana tabacum & GU369729 \\
\hline L3 & Bulgaria & Nicotiana tabacum & D13926 \\
\hline $20 \mathrm{Da} 96 / 1$ & Bulgaria & Dahlia sp. & AJ296602 \\
\hline GD98 & Bulgaria & Nicotiana tabacum & AJ297609 \\
\hline BS97 & Bulgaria & Nicotiana tabacum & AJ297610 \\
\hline 97 & Bulgaria & Nicotiana tabacum & AJ296598 \\
\hline T992 & Italy & Nicotiana tabacum & AY848922 \\
\hline P267 & Italy & Capsicum annuum & DQ376180 \\
\hline P105/2006RB & Italy & Capsicum annuum & DQ915946 \\
\hline C27084 & Czech Republic & Calla sp. & AJ296599 \\
\hline LE98/527 & Germany & Lysimachia sp. & AJ297611 \\
\hline $\mathrm{D}$ & The Netherlands & Dahlia sp. & AF020660 \\
\hline SPAIN-1 & Spain & Lycopersicon esculentum & AY744479 \\
\hline SPAIN-2 & Spain & Lycopersicon esculentum & AY744480 \\
\hline LC & Spain & $\rho^{\mathrm{a}}$ & X94550 \\
\hline VE430 & Spain & Capsicum annuum & DQ376184 \\
\hline France81 & France & Capsicum annuum & FR693053 \\
\hline SO46 & France & Lycopersicon esculentum & FR693255 \\
\hline MP & South Africa & Arachis hypogaea & EF059706 \\
\hline GP & South Africa & Arachis hypogaea & EF059705 \\
\hline NC-1 & North Carolina & Dahlia sp. & AY744476 \\
\hline 10 & North Carolina & Arachis hypogaea & AF020659 \\
\hline NC-3 & North Carolina & Dahlia sp. & AY744478 \\
\hline NC-2 & North Carolina & Arachis hypogaea & AY744477 \\
\hline $\mathrm{BL}$ & Hawaii & Lactuca sativa & L20953 \\
\hline $\mathrm{H}$ & Hawaii & l & AF306490 \\
\hline $\mathrm{L}$ & Hawaii & Lactuca sativa & X61799 \\
\hline $\mathrm{AC}$ & Georgia & Nicotiana tabacum & AF064469 \\
\hline MC & Georgia & Nicotiana tabacum & AF064472 \\
\hline CA-1 & California & Aster sp. & AY744468 \\
\hline $\mathrm{CA}-4$ & California & Chrysanthemum & AY744471 \\
\hline $\operatorname{Br} 20$ & Brazil & l & DQ915948 \\
\hline Iw & Japan & Lycopersicon esculentum & AB277581 \\
\hline $\mathrm{O}$ & Japan & Capsicum annuum & AB277582 \\
\hline Japan & Japan & 1 & AB010997 \\
\hline KAIxe & South Korea & Ixeris chinensis & EF195227 \\
\hline KAPo & South Korea & Capsicum annuum & EF195228 \\
\hline Sr-603 & Serbia & Lycopersicon esculentum & GU369723 \\
\hline $53-05 b$ & Serbia & Nicotiana tabacum & GQ373173 \\
\hline $33-06$ & Serbia & Nicotiana tabacum & GQ355467 \\
\hline $39-06$ & Serbia & Nicotiana tabacum & GQ373172 \\
\hline
\end{tabular}

${ }^{\mathrm{a}}$ Reference source included no host name; ${ }^{\mathrm{b}}$ Isolates in italics were amplified and sequenced in this study, other data are from GenBank.

and part of $3^{\prime}$ - and $5^{\prime}$-UTRs), TMV (complete CP gene and part of $3^{\prime}$ - and 5'-UTRs), and AMV (partial CP gene and $3^{\prime}$-UTR) were performed using RT-PCR with specific primers and cycling conditions (Table 1). RT-PCR was carried out with the One-Step RT-PCR kit (Qiagen, Hilden, Germany) according to the manufacturer's instructions. The RT-PCR reaction mixture included $400 \mu \mathrm{mol} / \mathrm{l}$ each of the four dNTPs, $0.6 \mu \mathrm{mol} / \mathrm{l}$ of the viral sense and complementary sense primer and $1 \mu \mathrm{l}$ extracted RNA in a final volume of $25 \mu \mathrm{l}$.
RT-PCR reaction was performed in a thermal cycler (Biometra, T-1 Thermocycler). PCR products were analyzed by $1 \%$ agarose gel electrophoresis, stained with ethidium bromide and visualized under a UV transilluminator.

Sequence analyses. Products of predicted size, which were amplified using specific primers to TSWV, PVY, CMV, TMV or AMV, were sequenced directly after the purification with QIAquick PCR Purification Kit (Qiagen). Sequencing was 
performed on an automated equipment (BMR Genomics, Padova, Italy) in both directions. All sequences generated in this study were deposited in the National Center for Biotechnology Information (NCBI) GenBank database and they were assigned by accession numbers. Sequences of Serbian virus isolates were compared with the respective virus sequences available in the GenBank (http://www.ncbi.nlm.nih.gov/BLAST/) using the ClustalW program (Thompson et al., 1994) and MEGA4 software (Tamura et al., 2007). A Kimura 2-parameter was applied for nucleotide, while p-distance model was used for deduced amino acid sequence analysis.

Selected NC-gene sequences of 38 TSWV isolates which were retrieved online from the NCBI and three sequences of Serbian tobacco isolates (Table 2) were trimmed to $744 \mathrm{bp}$, the length of the shortest fragment. Calculation of the divergence in NC-gene nucleotide sequences of selected isolates and phylogenetic analysis were conducted using the MEGA4 software. Phylogenetic trees were constructed using the maximum parsimony method and bootstrap analysis with 1,000 replicates. All branches with bootstrap value support $<50 \%$ were collapsed. An isolate of tomato chlorotic spot virus (TCSV; Acc. No. S54325) was used as the outgroup sequence.

\section{Results}

\section{Disease incidence and symptomatology in the field}

Disease incidence, as estimated by the number of symptomatic plants in the field, highly varied depending on the year and sampling locality. Disease incidence was estimated at 50 to $70 \%$ in years 2005 and 2006 , while it was nearly $100 \%$ in two fields in 2008. In 2007, virus-like symptoms were not recorded on six fields, while in other four fields

Table 3. Incidence of TSWV, PVY, CMV, TMV, and AMV in single and total infections in tobacco crops in Serbia

\begin{tabular}{|c|c|c|c|c|c|c|c|c|c|}
\hline \multirow{2}{*}{ Year } & \multirow{2}{*}{ District } & \multirow{2}{*}{ Locality } & \multirow{2}{*}{ Tobacco type } & \multirow{2}{*}{$\begin{array}{c}\text { No. of } \\
\text { samples }\end{array}$} & \multicolumn{5}{|c|}{ Single/total infection (\%) } \\
\hline & & & & & TSWV & PVY & $\mathrm{CMV}$ & TMV & AMV \\
\hline \multirow[t]{5}{*}{2005} & South Bačka & Bački Petrovac & Burley & 29 & $0 / 0$ & $44.8 / 58.6$ & $0 / 0$ & $41.4 / 55.2$ & $0 / 0$ \\
\hline & & Futog & Virginia & 14 & $0 / 0$ & $85.7 / 92.9$ & $0 / 14.3$ & $0 / 0$ & $0 / 0$ \\
\hline & & Begeč & Virginia & 7 & $0 / 0$ & $57.1 / 85.7$ & $14.3 / 42.9$ & $0 / 0$ & $0 / 0$ \\
\hline & Srem & Beška & Virginia & 16 & $37.5 / 62.5$ & $25.0 / 31.3$ & $0 / 0$ & $6.3 / 31.3$ & $0 / 0$ \\
\hline & City of Belgrade & Mladenovac & Burley & 7 & $28.6 / 71.4$ & $0 / 0$ & $14.3 / 54.1$ & $0 / 0$ & $0 / 0$ \\
\hline Subtotal & & & & 73 & $11.0 / 20.6$ & $45.2 / 56.2$ & $2.74 / 12.3$ & $17.8 / 30.1$ & $0 / 0$ \\
\hline \multirow[t]{7}{*}{2006} & South Bačka & Futog & Virginia & 24 & $0 / 0$ & $66.7 / 75$ & $16.7 / 25$ & $0 / 0$ & $8.3 / 8.3$ \\
\hline & Srem & Kuzmin & Virginia & 9 & $0 / 0$ & $55.6 / 55.6$ & $33.3 / 33.3$ & $0 / 0$ & $0 / 0$ \\
\hline & & Bačinci & Virginia & 12 & $0 / 0$ & $58.3 / 75$ & $25.0 / 41.7$ & $0.0 / 0.0$ & $0 / 0$ \\
\hline & & Kukujevci & Virginia & 12 & $0 / 0$ & $66.7 / 66.7$ & $25 / 25$ & $0.0 / 0.0$ & $0 / 0$ \\
\hline & & Hrtkovci & Virginia & 12 & $0 / 0$ & $66.7 / 83.3$ & $0 / 0$ & $16.7 / 25$ & $0 / 8.3$ \\
\hline & & Golubinci & Virginia & 10 & $0 / 0$ & $100 / 100$ & $0 / 0$ & $0 / 0$ & $0 / 0$ \\
\hline & & Beška & Virginia & 28 & $82.1 / 82.1$ & $7.1 / 7.1$ & $0.0 / 0.0$ & $7.1 / 7.1$ & $0 / 0$ \\
\hline Subtotal & & & & 107 & $21.5 / 21.5$ & $52.3 / 57.9$ & $12.2 / 15.9$ & $3.7 / 4.7$ & $1.9 / 2.8$ \\
\hline \multirow[t]{10}{*}{2007} & South Bačka & Bački Petrovac & Burley & 42 & $4.8 / 14.3$ & $0 / 35$ & $33.4 / 76.2$ & $0 / 19$ & $0 / 33.3$ \\
\hline & & Futog & Virginia & 16 & $0 / 12.5$ & $0 / 25$ & $0 / 87.5$ & $12.5 / 100$ & $0 / 12.5$ \\
\hline & Srem & Golubinci & Virginia & 8 & $0 / 0$ & $0 / 0$ & $0 / 0$ & $0 / 0$ & $0 / 0$ \\
\hline & & Bingula & Virginia & 6 & $0 / 0$ & $0 / 0$ & $0 / 0$ & $0 / 0$ & $0 / 0$ \\
\hline & & Hrtkovci & Virginia & 9 & $0 / 0$ & $0 / 0$ & $0 / 0$ & $0 / 0$ & $0 / 0$ \\
\hline & & Sremska Mitrovica & Virginia & 7 & $0 / 0$ & $0 / 0$ & $0 / 0$ & $0 / 0$ & $0 / 0$ \\
\hline & Mačva & Bogatić & Virginia & 5 & $0 / 0$ & $0 / 0$ & $0 / 0$ & $0 / 0$ & $0 / 0$ \\
\hline & & Morović & Virginia & 6 & $0 / 0$ & $0 / 0$ & $0 / 0$ & $0 / 0$ & $0 / 0$ \\
\hline & Central Banat & Zrenjanin & Burley & 8 & $87.5 / 87.5$ & $0 / 0$ & $0 / 0$ & $0 / 0$ & $0 / 0$ \\
\hline & City of Belgrade & Mladenovac & Burley & 25 & $100 / 100$ & $0 / 0$ & $0 / 0$ & $0 / 0$ & $0 / 0$ \\
\hline Subtotal & & & & 132 & $25.8 / 28.8$ & $0 / 13.6$ & $10.6 / 34.8$ & $1.5 / 18.2$ & $0 / 12.1$ \\
\hline \multirow[t]{2}{*}{2008} & Jablanica & Đinđuša & Virginia & 24 & $0 / 100$ & $0 / 25$ & $0 / 87.5$ & $0 / 50$ & $0 / 50$ \\
\hline & & Lapotince & Virginia & 44 & $9.1 / 100$ & $0 / 0$ & $0 / 36.4$ & $0 / 63.6$ & $0 / 63.6$ \\
\hline Subtotal & & & & 68 & $5.9 / 100$ & $0 / 8.8$ & $0 / 54.4$ & $0 / 58.8$ & $0 / 58.8$ \\
\hline Total & & & & 380 & $18.2 / 37.9$ & $23.4 / 33.4$ & $7.6 / 28.7$ & $5.0 / 23.9$ & $0.5 / 15.5$ \\
\hline
\end{tabular}


the disease incidence was very high, estimated at $80 \%$. This study indicated that each virus caused different and obvious symptoms in single infections. The presence of PVY was correlated with systemic yellowing with veinal necrosis and stem necrotic lesions, while a mild to severe mosaic, often with narrowing of leaf lamina, was associated with CMV. Plants infected with TMV expressed a mottling pattern of light and dark green areas of tissue with leaf deformation. In the case of TSWV infection, plants showed necrotic spots, brown oak-leaf patterns, blighting and withering of leaves, severe stem necrosis and stunting growth. AMV was distinct by causing an apparent bright yellow mosaic and sometimes chlorotic line patterns and vein clearing. Mixed infections caused variations of symptoms, which were not of preliminary diagnostic value.

\section{Virus detection and incidence in tobacco samples}

Viruses detected in the tobacco fields surveyed in years 2005-2008 were PVY, TSWV, CMV, TMV, and AMV. PVX and TRSV were not detected by ELISA in any of the 380 tobacco samples tested. The relative incidence and distribution of detected viruses in collected tobacco samples are presented in Table 3 and 4.
In year 2005, PVY was detected in almost all localities and was the most prevalent, followed by TMV, TSWV, and CMV. Single infections were predominant, while the most frequent type of mixed infections was PVY+TMV. The presence of AMV was not detected in any of tested samples. In $2.7 \%$ of collected symptomatic samples, presence of any of the tested viruses could not be detected.

In year 2006, PVY was also found most frequently and was detected in all surveyed localities. TSWV, CMV, TMV, and AMV were also detected, but at lower frequencies. The number of single infections was considerably higher than of double infections, which was the only mixed infection type found in 2006. The most frequent double infection was by PVY+CMV. In $2.8 \%$ of collected symptomatic samples, presence of any of the tested viruses could not be detected.

In year 2007, CMV was most frequently detected, followed by TSWV, TMV, PVY, and AMV. Single infections were predominant, but mixed infections with two, three and four viruses were also detected at high incidence level. Among mixed infections, most frequent infection was by CMV+TMV. Tested viruses were not detected in any of the symptomless samples (31.8\%) from six localities, as well as in $1.5 \%$ of symptomatic samples.

Table 4. Incidence of TSWV, PVY, CMV, TMV, and AMV in mixed infections in tobacco crops in Serbia

\begin{tabular}{|c|c|c|c|c|c|c|}
\hline \multirow[b]{2}{*}{ Year } & \multicolumn{2}{|c|}{ Double infected } & \multicolumn{2}{|c|}{ Triple infected } & \multicolumn{2}{|c|}{ Infected with four viruses } \\
\hline & Viruses & $\begin{array}{l}\text { Infected } \\
\text { samples }^{\mathrm{a}}\end{array}$ & Viruses & $\begin{array}{l}\text { Infected } \\
\text { samples }\end{array}$ & Viruses & $\begin{array}{l}\text { Infected } \\
\text { samples }\end{array}$ \\
\hline \multirow[t]{5}{*}{2005} & TSWV+CMV & $3 / 4.1$ & TSWV+PVY+TMV & $1 / 1.4$ & & \\
\hline & TSWV+TMV & $3 / 4.1$ & & & & \\
\hline & $\mathrm{PVY}+\mathrm{CMV}$ & $3 / 4.1$ & & & & \\
\hline & PVY+TMV & $4 / 5.5$ & & & & \\
\hline & CMV+TMV & $1 / 1.4$ & & & & \\
\hline Subtotal & & $14 / 19.2$ & & $1 / 1.4$ & & \\
\hline \multirow[t]{3}{*}{2006} & $\mathrm{PVY}+\mathrm{CMV}$ & $4 / 3.7$ & & & & \\
\hline & PVY+TMV & $1 / 0.9$ & & & & \\
\hline & $\mathrm{PVY}+\mathrm{AMV}$ & $1 / 0.9$ & & & & \\
\hline Subtotal & & $6 / 5.6$ & & & & \\
\hline \multirow[t]{6}{*}{2007} & TSWV+CMV & $2 / 1.5$ & $\mathrm{PVY}+\mathrm{CMV}+\mathrm{TMV}$ & $4 / 3.0$ & TSWV+CMV+TMV+AMV & $2 / 1.5$ \\
\hline & $\mathrm{PVY}+\mathrm{CMV}$ & $2 / 1.5$ & $\mathrm{PVY}+\mathrm{CMV}+\mathrm{AMV}$ & $6 / 4.6$ & & \\
\hline & $\mathrm{PVY}+\mathrm{TMV}$ & $2 / 1.5$ & $\mathrm{CMV}+\mathrm{TMV}+\mathrm{AMV}$ & $2 / 1.5$ & & \\
\hline & $\mathrm{PVY}+\mathrm{AMV}$ & $4 / 3.0$ & & & & \\
\hline & $\mathrm{CMV}+\mathrm{TMV}$ & $12 / 9.1$ & & & & \\
\hline & $\mathrm{CMV}+\mathrm{AMV}$ & $2 / 1.5$ & & & & \\
\hline Subtotal & & $24 / 18.2$ & & $12 / 9.1$ & & $2 / 1.5$ \\
\hline \multirow[t]{3}{*}{2008} & TSWV+CMV & $10 / 14.7$ & TSWV+CMV+TMV & $7 / 10.3$ & TSWV+PVY+CMV+TMV & $3 / 4.4$ \\
\hline & TSWV+TMV & $4 / 5.9$ & $\mathrm{TSWV}+\mathrm{CMV}+\mathrm{AMV}$ & $4 / 5.9$ & TSWV+PVY+CMV+AMV & $3 / 4.4$ \\
\hline & TSWV+AMV & $7 / 10.3$ & TSWV+TMV+AMV & $16 / 23.5$ & TSWV+CMV+TMV+AMV & $10 / 14.7$ \\
\hline Subtotal & & $21 / 30.9$ & & $27 / 39.7$ & & $16 / 23.5$ \\
\hline Total & & $65 / 17.1$ & & $40 / 10.5$ & & $18 / 4.7$ \\
\hline
\end{tabular}

${ }^{a}$ Number of mixed infected samples/incidence of mixed infection in $\%$. 
Table 5. List of TSWV, PVY, CMV, TMV, and AMV isolates analyzed in this study

\begin{tabular}{lllll}
\hline Virus & Isolate & $\begin{array}{l}\text { Year of } \\
\text { isolation }\end{array}$ & Locality & Acc. No. \\
TSWV & $53-05$ & 2005 & Mladenovac & GQ373173 \\
& $33-06$ & 2006 & Beška & GQ355467 \\
& $39-06$ & 2006 & Beška & GQ373172 \\
PVY & D7-06 & 2006 & Futog & GQ290476 \\
& D35-06 & 2006 & Beška & GQ290475 \\
CMV & $702-07$ & 2008 & Futog & GQ340670 \\
TMV & $699-07$ & 2007 & Futog & GQ340671 \\
AMV & $196-08$ & 2008 & Đinđuša & FJ527749 \\
\hline
\end{tabular}

In year 2008, TSWV was detected most frequently and was the only virus present in single infections. TMV, AMV, and CMV were less frequent than TSWV, but present at high infection rates. PVY was present at much lower level than in previous years. The number of mixed infections was considerably higher than of single. Triple infections were found to be the most frequent, and the most often viral combination was TSWV+TMV+AMV.

In general, TSWV was the most frequent virus identified in $37.9 \%$ of 380 samples collected during the investigation. The second most frequent was PVY, which infected 33.4\% of tested samples. All of 127 samples which were ELISApositive for the presence of PVY reacted with MAb specific for $\mathrm{PVY}^{\mathrm{N}}$, revealing $\mathrm{N}$ serotype. In all tested samples, no specific reactions were detected with $\mathrm{PVY}^{\mathrm{C}}$ or $\mathrm{PVY} \mathrm{Y}^{\mathrm{O}+\mathrm{C}}$. TSWV was most frequently found virus in the localities of Central Serbia, while PVY and CMV were the most frequent viruses in the Vojvodina Province. Most often detected single infection in all the collected samples was PVY, followed by the infection with TSWV. Mixed infections were the most frequent infection types in 2008. It was found in this study that variation and severity of disease symptoms were not dependent on tobacco types. Also, substantial differences in the incidence of viruses could not be recorded between these two tobacco types.

\section{Molecular detection and sequence identity analyses}

With TSWV, PVY, CMV, TMV, and AMV specific primers, we were able to amplify target cDNA fragments of predicted size and successfully detect the presence of respective viruses in all selected ELISA-positive samples. There was no amplification recorded in the healthy tobacco control. The identities of obtained amplicons were confirmed by sequencing. Sequences of five tobacco virus isolates determined in this study were submitted to GenBank and allocated under accession numbers (Table 5).

The identities of isolates 53-05 (GQ373173), 33-06 (GQ355467) and 39-06 (GQ373172) with 38 TSWV isolates selected for phylogenetic analysis varied from $96.2-100 \%$ at the nucleotide (nt) level. Nucleotide sequences of isolates 53-05 and 33-06 had the highest nt identity of 100\% with

Table 6. Nucleotide and deduced amino acid homology of the P1 gene sequences of Serbian isolates with 17 other PVY sequences retrieved from GenBank database

\begin{tabular}{|c|c|c|c|c|c|}
\hline $\begin{array}{l}\text { PVY } \\
\text { strain group }\end{array}$ & $\begin{array}{l}\text { Geographical } \\
\text { origin }\end{array}$ & Isolate & Acc. No. & GQ290476 & GQ290475 \\
\hline & Serbia & D7-06 & GQ290476 & & \\
\hline & & D35-06 & GQ290475 & $99.9 / 100^{\mathrm{a}}$ & \\
\hline \multirow[t]{13}{*}{$\mathrm{PVY}^{\mathrm{N}} / \mathrm{PVY}^{\mathrm{NTN}}$} & Slovenia & Sl-64 & AF401604 & $99.9 / 100$ & $100 / 100$ \\
\hline & & Sl-50 & AF401603 & $99.5 / 100$ & $99.6 / 100$ \\
\hline & & Slovenia & AJ315739 & $99.7 / 99.6$ & $99.9 / 99.6$ \\
\hline & Italy & $\mathrm{Pa} 21$ & GU550516 & $99.3 / 100$ & $99.5 / 100$ \\
\hline & Germany & Linda & AJ890345 & $98.6 / 98.0$ & $98.8 / 98.0$ \\
\hline & Great Britain & v942490 & EF016294 & $99.5 / 100$ & $99.6 / 100$ \\
\hline & & SASA 207 & AJ584851 & $99.5 / 100$ & $99.3 / 100$ \\
\hline & Denmark & Denmark & AJ315738 & $99.0 / 99.2$ & $99.2 / 99.2$ \\
\hline & Hungary & Hungarian & M95491 & $98.8 / 98.4$ & 98.9/98.4 \\
\hline & France & 204-Fr & AF248499 & $98.6 / 98.4$ & $98.8 / 98.4$ \\
\hline & The USA & California & AJ315744 & $91.8 / 92.7$ & $92.0 / 92.7$ \\
\hline & & $\mathrm{Tu}-660$ & AF401609 & $91.3 / 91.8$ & $91.5 / 91.8$ \\
\hline & & N 27 & AF401606 & $91.2 / 91.0$ & $91.3 / 91.0$ \\
\hline \multirow[t]{2}{*}{$\mathrm{PVY}^{\mathrm{O}}$} & Finland & 803 & AJ245555 & $63.3 / 70.6$ & $63.5 / 70.6$ \\
\hline & Canada & O-139 & U09509 & $62.5 / 69.4$ & $62.7 / 69.4$ \\
\hline \multirow[t]{2}{*}{$\mathrm{PVY}^{\mathrm{C}}$} & France & Adgen & AJ890348 & $63.2 / 68.6$ & $63.1 / 68.6$ \\
\hline & Spain & LYE84.2 & AJ439545 & $62.2 / 69.4$ & $62.4 / 69.4$ \\
\hline
\end{tabular}

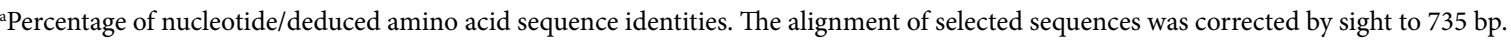




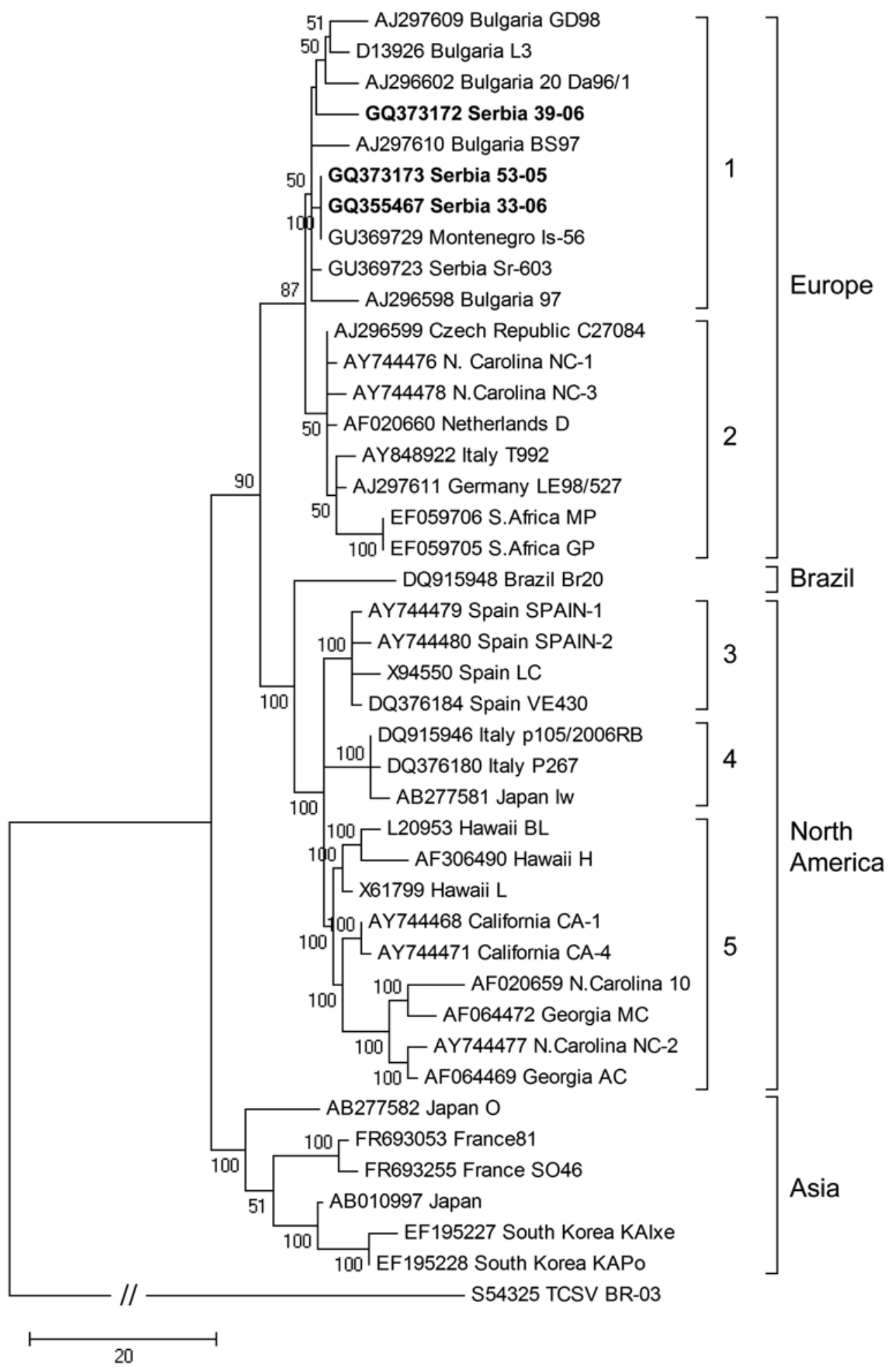

Fig. 1

Maximum parsimony tree of TSWV isolates was constructed with 744 bp partial NC sequence and shows relationships between 3 Serbian isolates (marked in bold) and other isolates from GeneBank 
each other and with Montenegrin tobacco isolate Is-56 (GU369729). Isolate 39-06 shared the highest nt similarity of $99.2 \%$ (100\% aa identity) with isolates 53-05 and 33-06, as well as with Serbian tomato isolate Sr-603 (GU369723) and Is-56 from Montenegro.

The BLAST analysis revealed that the sequences of isolates D7-06 (GQ290476) and D35-06 (GQ290475) were over $88 \%$ identical with the known PVY isolates. The sequences of these two isolates proved to be identical at nt level of 99.9\% (100\% aa identity). Multiple nucleotide and deduced amino acid comparison of the 735 bp of the partial P1 protein gene sequences revealed that nt sequences of Serbian isolates showed the highest homology of 91.2 to $100 \%$ (91 to $100 \%$ aa identities) with isolates belonging to $\mathrm{PVY}^{\mathrm{N}} /$ $\mathrm{PVY}^{\mathrm{NTN}}$ strain group, and the highest similarity (99.9-100\% nt and $100 \%$ aa identities) was with the Slovenian PVY ${ }^{\mathrm{NTN}}$ isolate (AF401604) (Table 6). However, sequence homology between isolates from Serbia and isolates belonging to $\mathrm{PVY}$ and $\mathrm{PVY}^{\mathrm{C}}$ strains was much lower, ranging from 62.5 to $63.5 \%$ (69.4 to $70.6 \%$ aa identities) and 62.2 to $63.2 \%$ (68.6 to $69.4 \%$ aa identities), respectively.

In the BLAST search analysis, the sequence of isolate 702-07 (GQ340670) showed over 94\% of sequence identity with the $\mathrm{CP}$ gene sequences of $\mathrm{CMV}$ from other parts of the world, and revealed the highest nt homology of $99.7 \%$ (100\% aa identity) with two isolates from Spain (AJ829770, AM183119) and one from USA (D10538). The BLAST analysis showed that the sequence of Serbian isolate 699-07 (GQ340671) was over 86\% identical with TMV sequences from other parts of the world. Isolate 699-07 shared the highest nt similarity of $97.4 \%$ (100\% aa identity) with German isolate (AJ429078). The 604 bp long CP gene sequence of Serbian isolate 196-08 (FJ527749) was over 93\% identical with the known AMV sequences, and the highest homology of 99\% (99.5\% aa identity) was with Chinese isolate (HQ316637) and USA isolate (HQ185569).

\section{Phylogenetic analysis of TSWV isolates}

The consensus tree was inferred from 49 most parsimonious trees (Fig. 1). The overall level of nucleotide diversity of the NC-gene sequences was $0.023 \pm 0.003$. The phylogenetic tree, supported with high bootstrap values, resulted in four major clusters: Europe (intragroup diversity of $0.010 \pm 0.002)$, North America (0.016 \pm 0.003$)$, Brazil and Asia $(0.020 \pm 0.004)$, with mean distance among these clusters ranging from $0.027 \pm 0.005$ to $0.039 \pm 0.007$.

The European cluster could be further divided into two geographical subpopulations with isolates from: Bulgaria, Serbia and Montenegro with the mean nucleotide intragroup divergence of $0.008 \pm 0.002$ (subgroup 1), and the Netherlands, Czech Republic, Germany, and Italy with the exception of the two isolates collected in North Carolina (NC-1 and
NC-3) and two collected in South Africa (MP and GP) with intragroup diversity of $0.006 \pm 0.002$ (subgroup 2). Genetic diversity between these two subgroups was $0.012 \pm 0.003$. According to the phylogenetic analysis, the relationship between the Serbian TSWV isolates and isolates from Bulgaria and Montenegro was closer than with TSWV isolates from other European countries. Subgroups 1 and 2 are polyphyletic, so bootstrap values associated with them were low (50\%). The isolates of North American cluster could be divided into three geographical subpopulations. Subgroup 3 included the isolates from Spain $(0.005 \pm 0.002)$, subgroup 4 isolates from Italy and Japan $(0.003 \pm 0.002)$, and subgroup 5 isolates from USA $(0.016 \pm 0.003)$. The mean distance among subgroups 3, 4 and 5 ranged from $0.014 \pm 0.003$ to $0.018 \pm 0.004$. Brazilian cluster consisted of single isolate. The phylogenetic tree also revealed a joint clustering of two French isolates (France81 and SO46) and Japanese and South Korean isolates in Asian cluster (0.020 \pm 0.004$)$.

\section{Discussion}

This study revealed presence of five viruses in tobacco crops in Serbia: PVY, TSWV, CMV, TMC, and AMV, in both, single and mixed infection. RT-PCR tests on few randomly selected samples which were ELISA-positive for the presence of respective viruses, as well as the comparisons of obtained virus isolate sequences with those available in NCBI, confirmed the authenticity of these viruses.

The occurrence, distribution and incidence of detected viruses varied from year to year, as it had been observed in tobacco crops worldwide (Pappu et al., 2000a; Mayunga and Kapooria, 2003; Chatzivassiliou et al., 2004), showing that the epidemic composition of tobacco viruses had constantly fluctuating trend. Widespread occurrence and the prevalence of PVY and TSWV, which were most frequently detected viruses in collected samples, implicated their major impact on tobacco production in Serbia. Extensive spread of TSWV and PVY was mainly recorded in Central Serbia and the Vojvodina Province, respectively. Although CMV, TMV, and AMV incidence in surveyed fields was significantly lower and their distribution was not so wide, the occurrence of these viruses should not be neglected because their populations are well established in tobacco crops in Serbia.

In majority of surveyed tobacco localities in Serbia, a broad range of symptoms was found. Only in 2007, viruslike symptoms were not observed and there was not any virus infection detected in collected samples from six inspected fields. It was expected, since these fields were surrounded by large maize- or wheat-growing fields, and they were spatially isolated from crops which could be the source of viral inoculum. During years 2007 and 2008, especially in the fields located in Central Serbia, the incidence of severe leaf 
symptoms and dwarfed plants was very high, which caused considerable yield losses and abandoning of some crops. This situation might be explained by facts that most widely planted tobacco cultivars in Serbia are highly susceptible (Djekić et al., 2006) and that mixed infections were more common than in previous years.

Infections with TSWV were recorded mainly in Central Serbia. These infections were serious and affected the whole plants, causing yield losses or even total loss, as it was in 2008. Therefore, the incidence of TSWV at an economically damaging level and extremely severe symptoms represented serious threat for tobacco in Serbia, as it was reported for many tobacco-growing regions in the world. TSWV infection was responsible for destructive epidemics in tobacco throughout USA (Pappu et al., 2000b), in Eastern Europe and Balkan countries (Chatzivassiliou et al., 2004; Hristova et al., 2001). Recent first report on TSWV in tobacco in Italy indicated its further spread in tobacco in Europe (Carrieri et al., 2011).

TSWV has been reported as an economically important constraint to the production of field crops, vegetables and ornamentals in Serbia (Krstić and Bulajić, 2007). However, little information is available on the sequence characteristics of natural populations of TSWV (Stanković et al., 2011) and there is not any information on TSWV tobacco isolates from Serbia. The sequences of Serbian TSWV isolates were highly homologous to each other and to the NC-gene sequences of TSWV isolates from other parts of the world. Previous studies showed a high degree of NC-gene sequence identity of TSWV isolates sampled from a single crop (Kaye et al., 2011), as well as of its global populations (Pappu et al., 1998; Tsompana et al., 2005; Sivparsad and Gubba, 2008). In spite of the high degree of NC-gene sequence identity among TSWV isolates used in this study, phylogenetic analysis revealed that minor differences may be of potential significance, because NC phylogenetic tree of selected TSWV isolates clustered by geographic origin, with some exceptions. The overall level of nucleotide diversity of the NC-gene sequences compared in this study was similar to global TSWV population diversity (0.024), reported previously (Tsompana et al., 2005). Clustering of TSWV isolates based on geographic origin was also reported previously (Pappu et al., 1998; Tsompana et al., 2005), as well as the lack of clustering among Australian isolates (Dietzgen et al., 2005). Three isolates originating from Serbia, clustered with isolates from Bulgaria and Montenegro, but other European isolates formed close related, but different geographical subpopulation. Clustering of European TSWV isolates in two geographical subpopulations may be due to the evolution of geographically distinct sequence variants in the natural population of TSWV. The high sequence similarity among Serbian, Bulgarian and Montenegrin TSWV isolates suggested that gene flow had occurred among these three countries. Similarly, it was reported that the isolates from Georgia and North Carolina formed one tight cluster that was distinct from TSWV isolates reported from other parts of the USA and the world (Tsompana et al., 2005). Serbian tobacco TSWV isolates not only shared a high sequence similarity among each other, but they were also very similar to one Serbian TSWV isolate from tomato. A large number of hosts and geographically diverse isolates should be sequenced and phylogenetically analyzed in order to provide complete information on TSWV natural populations in Serbia.

The phylogenetic analysis performed in this study showed that TSWV had a defined geographical structure with exception of the two isolates from North Carolina and two from South Africa, which were placed into European cluster, demonstrating the trans-continental dispersal from Europe to North America and South Africa, as it was stated by Tsompana et al. (2005) and Sivparsad and Gubba (2008). Also, NC-gene sequences of two French isolates were most closely related to, and clustered with South Korean isolates, indicating genetic exchanges between Asian and European groups. Study of Tentchev et al. (2011) revealed that European and Asian clusters clearly diverged from North American cluster representing local outbreaks of indigenous TSWV populations. The clustering of some isolates from Spain and Italy into North American, and some French isolates into Asian cluster, suggested at least three independent introductions of TSWV in Europe, which was consistent with the results of a pioneering study (Tsompana et al., 2005) and most recent comprehensive study on TSWV evolution and population structure (Tentchev et al., 2011).

In 2005 and 2006, the most frequently observed symptom was venial necrosis, which was extended throughout the plant causing reddish-brown plant colour and premature death of lower leaves. Serious yield losses associated with these symptoms were recorded mainly at localities in northern part of the country. In all collected samples with this type of symptoms, presence of PVY was detected. PVY which is one of the most destructive tobacco pathogens (Chatzivassiliou et al., 2004) is widely distributed in Serbia. It was the most prevalent virus in the first two years of investigation, but its presence was significantly lower in the two subsequent years. The similar situation was reported in Georgia's fluecured tobacco, when PVY was predominant in 1999, while none of tested plants were PVY-positive in the next year (Pappu et al., 2000a).

Symptoms observed in tobacco crops suggested the presence of a PVY necrotic strain, which was confirmed by reaction with a $\mathrm{PVY}^{\mathrm{N}}$-specific MAbs. The results of $\mathrm{P} 1$ gene sequence similarity analysis, confirmed by phylogenetic analysis (data not shown), revealed the highest sequence similarity of two Serbian PVY isolates with European $\mathrm{PVY}^{\mathrm{N}} / \mathrm{PVY}^{\mathrm{NTN}}$ isolates, a little lower homology with North American isolates of necrotic strains, and significantly 
lower homology with $\mathrm{PVY}^{\mathrm{O}}$ and $\mathrm{PVY}^{\mathrm{C}}$ isolates. Nie and Singh (2002) also found that typical PVYN/PVY ${ }^{\mathrm{NTN}}$ isolates showed only $70 \%$ identity with known $\mathrm{PVY}$ isolates, while high identity was determined among necrotic strains from Europe and North America. Taking into account significant PVY genetic variation, the highest sequence identity of Serbian PVY isolates with the Slovenian PVY ${ }^{\text {NTN }}$ isolate, as well as the fact that PVY ${ }^{\mathrm{NTN}}$ and $\mathrm{PVY}^{\mathrm{N}}$ isolates had identical serotype and tobacco phenotype, detailed characterization of PVY isolates is needed to achieve final classification of PVY tobacco isolates from Serbia.

Tobacco crops worldwide are regularly threatened by CMV and severe epidemics were sometimes associated with this virus (Kucharek et al., 1998; Gooding, 1991; Chatzivassiliou et al., 2004). Its prevalence was the highest of all the viruses identified in Florida during a 3-year period (Kucharek et al., 1998), although the prevalence and severity of its outbreaks could vary from year to year (Li et al., 2001). During the 4-year period of this investigation, CMV was identified every year and it was present in almost all sampling localities in Serbia. Significant difference was seen between the infection level in the first two years of the survey, when CMV occurred at lower degree, and in the last two years, when the virus became prevalent or frequently detected. Apart from TSWV and PVY, CMV is also a persistent threat for Serbian tobacco production.

Among the other viruses found in tobacco crops in Serbia, TMV also occupied an important position, not only because it was present throughout the country, but it was also the second most frequently detected virus in two years of the investigation. TMV infects commercially grown tobacco worldwide, reducing its quality and yields. Sometimes this virus occurred rarely (Li et al., 2001), but sometimes severe outbreaks were reported (Pappu et al., 2000a; Mayunga and Kapooria, 2003). Relative high incidence and constant presence in Serbian tobacco crops resulted likely from insufficient growers understanding that the mechanical transmission by contaminated tools or workers themselves is of major importance for a quick and effective TMV infection, which spreads easily. This indicated the need to enhance growers awareness of the importance of good sanitation, as the best means of preventing TMV.

AMV was another virus identified in this study, present in a limited number of crops and occurred to a lesser extent than the other detected viruses. Tobacco is not a major host for AMV and reports on its natural infections in field-grown tobacco are limited. However, AMV was often found in tobacco cultivated in the vicinity of alfalfa crops where virus incidence was high (Tedford and Nielsen, 1990). Only in 2008, AMV was detected in more than $50 \%$ of tested samples, and all these samples were infected with various combinations of the viruses. Despite the high incidence of AMV in alfalfa crops in Serbia (Bulajić et al., 2010), its incidence in tobacco crops remained lower than of the other aphid transmitted viruses, and it was not economically significant for Serbian tobacco production.

This investigation provides essential basic information useful for tobacco virus control in Serbia. Damage caused by tobacco viruses should initiate a breeding program aimed at genotype selection for the resistance against the most prevalent viruses. An important option for virus disease control would be to enhance growers acquaintance with control measures against tobacco viruses and their vectors, especially those directed to limit early virus infections.

Acknowledgement. This research was supported by grants III43001 and TR-31025 from the Ministry of Science and Technological Development, Republic of Serbia.

\section{References}

Bulajić A, Vučurović A, Stanković I, Ristić D, Ivanović M, Krstić B (2010): Development of method for assessing AMV incidence in alfalfa seed crop. Proc. X National Conf. Plant Protec. Zlatibor, pp. 77-78 (in Serbian).

Carrieri R, Sorrentino R, Lahoz E, Alioto D (2011): First Report of Tomato spotted wilt virus on Tobacco in Campania, Italy. Plant Dis. 95, 611. http://dx.doi.org/10.1094/PDIS01-11-0045

Chatzivassiliou EK, Efthimiou K, Drossos E, Papadopoulou A, Poimenidis G, Katis NI (2004): A survey of tobacco viruses in tobacco crops and native flora in Greece. Eur. J. Plant Pathol. 110, 1011-1023. http://dx.doi.org/10.1007/ s10658-004-1598-1

Chatzivassiliou EK, Weekes R, Morris J, Wood KR, Barker I, Katis NI (2000): Tomato spotted wilt tospovirus in Greece: its incidence following the expansion of Frankliniella occidentalis, and characterization of isolates collected from various hosts. Ann. Appl. Biol. 137, 127-134. http:// dx.doi.org/10.1111/j.1744-7348.2000.tb00044.x

Dietzgen RG, Twin J, Talty J, Selladurai S, Carroll ML, Coutts BA, Berryman DI, Jones RAC (2005): Genetic variability of Tomato spotted wilt virus in Australia and validation of real time RT-PCR for its detection in single and bulked leaf samples. Ann. Appl. Biol. 146, 517-530. http://dx.doi. org/10.1111/j.1744-7348.2005.040155.x

Djekić I, Bulajić A, Vučurović A, Krstić B, Jović J, Krnjajić S, Berenji $J$ (2008): Frequency and molecular detection of Cucumber mosaic virus in tobacco crops. Bulletin for Hops, Sorghum and Medicinal Plants 40, 70-82 (in Serbian).

Djekić I, Dukić N, Bulajić A, Berenji J, Duduk B, Antonijević D, Krstić B (2006): Characterization of Tomato spotted wilt virus and level of resistance of some tobacco genotypes in Serbia. Proc. VIII National Conf. Plant Protec. Zlatibor, pp. 69-70 (in Serbian).

Dukić N, Bulajić A, Berenji J, Đekić I, Duduk B, Krstić B (2006): Occurrence and distribution of tobacco viruses in Serbia. Pestic. Phytomed. (Belgrade) 21, 205-214 (in Serbian). 
Finetti-Sialer MM, Di Franco A, Papanice MA, Gallitelli D (1997): Tomato necrotic yellows induced by a novel strain of Alfalfa mosaic virus. J. Plant Pathol. 79, 115-120.

Glais L, Tribodet M, Kerlan C (2002): Genomic variability in Potato potyvirus Y (PVY): evidence that PVYNW and PVYNTN variants are single to multiple recombinants between PVYO and PVYN isolates. Arch. Virol. 147, 363-378. http://dx.doi.org/10.1007/s705-002-8325-0

Gooding GV (1991): Disease caused by viruses. In Shew HD, Lucas GB (Eds): Compendium of Tobacco Diseases. American Phytopathological Society, St. Paul, MN, pp. 41-47.

Hristova D, Karadjova O, Yankulova M, Heinze C, Adam G (2001): A survey of tospoviruses in Bulgaria. J. Phytopathology 149, 745-749. http://dx.doi.org/10.1046/j.14390434.2001.00694.x

Jain RK, Pappu SS, Pappu HR, Culbreath AK (1998): Molecular diagnosis of Tomato spotted wilt tospovirus infection of peanut and other field and greenhouse crops. Plant Dis. 82, 900-904. http://dx.doi.org/10.1094/ PDIS.1998.82.8.900

Jasnić S, Bagi F, Berenji J, Jelinčić K, Mumović J (2000): Distribution of tobacco viruses in the Vojvodina province. Proceedings of the Institute of Field and Vegetable Crops (Novi Sad) 34, 67-76 (in Serbian).

Kaye AC, Moyer JW, Parks EJ, Carbone I, Cubeta MA (2011): Population genetic analysis of Tomato spotted wilt virus on peanut in North Carolina and Virginia. Phytopathology 101, 147-153. http://dx.doi.org/10.1094/ PHYTO-01-10-0035

Krstić B, Bulajić A (2007): Quarantine viruses in protected vegetable and ornamental crops. University of Belgrade-Faculty of Agriculture and Ministry of Agriculture, Forestry, and Water Management of Serbia, Belgrade, pp. 11-64 (in Serbian).

Kucharek TA, Purcifull DE, Christie RG, Perkins KD (1998): The association of severe epidemics of Cucumber mosaic in commercial fields of pepper and tobacco in North Florida with inoculum in Commelina benghalensis and C. communis. Plant Dis. 82, 1172. http://dx.doi.org/10.1094/ PDIS.1998.82.10.1172A

Letschert B, Adam G, Lesemann DE, Willingmann P, Heinze C (2002): Detection and differentiation of serologically cross- reacting Tobamoviruses of economical importance by RT-PCR-RFLP. J. Virol. Methods 106, 1-10. http:// dx.doi.org/10.1016/S0166-0934(02)00135-0

Li XD, Li YQ, Wang HG (2001): Epidemic of Potato virus Y and Cucumber mosaic virus in Henan Province Tobacco. Plant Dis. 85, 447. http://dx.doi.org/10.1094/ PDIS.2001.85.4.447C

Mayunga DS, Kapooria RG (2003): Incidence and identification of virus diseases of tobacco in three provinces of Zambia. Bull. OEPP/EPPO Bull. 33, 355-359.
Nie X, Singh RP (2002): Probable geographical grouping of PVYN and PVYNTN based on sequence variation in P1 and 5'-UTR of PVY genome and methods for differentiating North American PVYNTN. J. Virol. Methods 103, 145156. http://dx.doi.org/10.1016/S0166-0934(02)00023-X

Pappu HR, Bertrand PF, Moore JM (2000a): A severe outbreak of Tobacco mosaic virus in Georgia's flue-cured tobacco. Plant Dis. 84, 1047. http://dx.doi.org/10.1094/ PDIS.2000.84.9.1047C

Pappu HR, Csinos AS, McPherson RM, Jones DC, Stephenson MG (2000b): Effect of acibenzolar-S-methyl and imidacloprid on suppression of tomato spotted wilt Tospovirus in fluecured tobacco. Crop Prot. 19, 349-354. http://dx.doi. org/10.1016/S0261-2194(00)00028-4

Pappu HR, Pappu S, Jain R, Bertrand P, Culbreath A, McPherson R, Csinos A (1998): Sequence characteristics of natural populations of Tomato spotted wilt tospovirus infecting flue-cured tobacco in Georgia. Virus Genes 17, 169-177. http://dx.doi.org/10.1023/A:1008072825152

Sivparsad BJ, Gubba A (2008): Isolation and molecular characterization of Tomato spotted wilt virus (TSWV) isolates occurring in South Africa. Afr. J. Agric. Res. 3, 428-434.

Stanković I, Bulajić A, Vučurović A, Ristić D, Jović J, Krstić B (2011): First report of Tomato spotted wilt virus on Gerbera hybrida in Serbia. Plant Dis. 95, 226. http://dx.doi. org/10.1094/PDIS-10-10-0704

Tamura K, Dudley J, Nei M, Kumar S (2007): MEGA4: Molecular Evolutionary Genetics Analysis (MEGA) software version 4.0. Mol. Biol. Evol. 24, 1596-1599. http://dx.doi. org $/ 10.1093 / \mathrm{molbev} / \mathrm{msm} 092$

Tedford EC, Nielsen MT (1990): Response of burley tobacco cultivars and certain Nicotiana spp. to Alfalfa mosaic virus. Plant Dis. 74, 956-958. http://dx.doi.org/10.1094/ PD-74-0956

Tentchev D, Verdin E, Marchal C, Jacquet M, Aguilar JM, Moury B (2011): Evolution and structure of Tomato spotted wilt virus populations: evidence of extensive reassortment and insights into emergence processes. J. Gen. Virol. 92, 961-973. http://dx.doi.org/10.1099/vir.0.029082-0

Thompson JD, Higgins DG, Gibson TJ (1994): CLUSTAL W: Improving the sensitivity of progressive multiple sequence alignment through sequence weighting, position-specific gap penalties and weight matrix choice. Nucleic Acids Res. 22, 4673-4680. http://dx.doi.org/10.1093/nar/22.22.4673

Tsompana M, Abad J, Purugganan M, Moyer JW (2005): The molecular population genetics of the Tomato spotted wilt virus (TSWV) genome. Mol. Ecol. 14, 53-66. http:// dx.doi.org/10.1111/j.1365-294X.2004.02392.x

Williams-Woodward JL (2000): 1999 Georgia plant disease loss estimates. Univ. Georgia Coop. Ext. Serv. Publ. Path. 99-002, p. 18. 